\title{
The Insulin-Like Growth Factor I (IGF-I) Within the Bony Fish Pituitary: New Morphofunctional and Phylogenetic Aspects
}

\author{
Elisabeth Eppler*
}

Research Group Neuro-endocrine-immune Interactions, Institute of Anatomy, University of Zürich, Zürich, Switzerland

\begin{abstract}
IGF-I is a major hormonal regulator of differentiation, growth, proliferation, and development. It is mainly produced in the liver, the principal source of endocrine IGF-I. The main stimulus for synthesis and release of liver IGF-I is growth hormone $(\mathrm{GH})$ from the anterior pituitary, and IGF-I specifically inhibits GH gene transcription and secretion via a negative feedback mechanism. As shown for species throughout phylogeny, IGF-I is also produced in extrahepatic sites, including the pituitary, and very recently, new insights have been achieved into the distinct localization of IGF-I. Bony fish pituitary preserves the embryonic compartmentalization throughout life, thus, each endocrine cell type is situated in a distinct region. This makes fish pituitary an excellent tool for morphologic investigations. IGF-I mRNA and/or peptide has been located to subtypes of endocrine cells with similar distribution patterns in lower and higher vertebrates suggesting highly conserved and, thus, important physiological roles of intrapituitary IGF-I. Since a major task of IGF-I is to prevent apoptosis and promote cell proliferation, IGF-I released from the endocrine adenohypophyseal cells may have protective and proliferative autocrine and/or paracrine effects. This is supported by the presence of the type 1 IGF receptor (IGF-1R) at all endocrine subpopulations as has been shown in rat and by the constitutive presence of IGF-I in ACTH cells in bony fish and mammals. ACTH cells probably are challenged in stressful situations by pro-apoptotic cytokines and hormones, and might, thus, have a special demand for IGF-I. The increased transient expression of IGF-I in gonadotrophs during puberty, and in subordinate males of tilapia suggests an impact in sexual differentiation and maturation, a question which has been recently underlined to be of major importance. The pronounced inter-individual differences in the IGF-I content of the GH cells may indicate that synthesis and release of IGF-I from GH cells depend on the physiological status, most likely the serum IGF-I level. Further studies should be performed to elucidate these morphofunctional observations.
\end{abstract}

Keywords: ACTH, GH, FSH, LH, IGF-I, prolactin, TSH, $\alpha$-MSH, somatotroph, gonadotroph, feed-back mechanism, intrapituitary loop, adenohypophysis, neurohypophysis, phylogeny, ontogeny.

\section{THE ROLE OF THE PITUITARY IN THE GH/IGF-I AXIS}

IGF-I is a major hormonal regulator of differentiation, growth, proliferation, and development as has been established in mammals [1, 2]. IGF-I is mainly produced in the liver, the principal source of endocrine IGF-I. The main stimulus for synthesis and release of liver IGF-I is GH released from the anterior pituitary under the control of $\mathrm{GH}$ releasing (GH-RH) and -inhibiting (somatostatin) hormone, while IGF-I specifically inhibits GH gene transcription and secretion via a negative feedback mechanism as shown in vivo and in vitro [3-5]. The suppressive action of IGF-I on GH synthesis and secretion is exerted at the pituitary level [3] and probably mediated via the IGF-1R which has been identified in clawed frog [6], rat [7-10], ovine [11] and mouse [12] pituitary, particularly on GH cells $[10,13,14]$. In particular, the concentration of serum IGF-I stimulates or suppresses GH release from the anterior pituitary via a feedback loop in mammals and in lower vertebrates, as has been demonstrated particularly in bony fish [15]. Thus, in

\footnotetext{
*Address correspondence to this author at the Research Group Neuroendocrine-immune Interactions, Institute of Anatomy, University of Zürich, Winterthurerstr. 190, CH-8057 Zürich, Switzerland; Tel: ++/41/044-6355333; Fax: ++/41/044-6355702; Email: eppler@anatom.uzh.ch.
}

both mammals and bony fish the pituitary GH/liver IGF-I axis involved in the endocrine regulation of crucial physiological processes seems to exist $[16,17]$.

In addition, organ-specific extrahepatic synthesis sites of IGF-I have been described in various tissues throughout phylogeny [15] indicating specific roles of local autocrine/paracrine IGF-I in numerous physiological mechanisms, such as growth, differentiation, maintenance, reproduction, and metabolism.

There is evidence that IGF-I is also expressed in the pituitary as has been shown to date for bony fish species (see below), frog [6], rat [9, 10, 18-20] and human [21, 22].

Thus, the question arises what the physiological function of local IGF-I in the pituitary might be? In order to get some idea of the potential role of IGF-I in pituitary it is essential to identify its localization sites. In adult mammalian adenohypophysis the diverse hormone-producing subpopulations are intermingled cell clusters forming a mosaic pattern. In rat, IGF-I mRNA has been found to be evenly distributed throughout the anterior pituitary [18, 23] and was thought to be expressed either by all endocrine or by folliculo-stellate cells [23]. While IGF-I-immunoreactive cells were described as non-hormone-producing cells in human pituitary [24], in a mouse pituitary cell culture IGF-I 
immunoreactivity was confined to endocrine cells [12], and in accordance to the latter, both IGF-I mRNA and peptide were recently localised in distinct endocrine cells of the adenohypophysis of rat [10], human [22] and the bony fish tilapia [25].

The hypothesis of a stimulatory role in the pituitary as raised for IGF-I $[10,12,22,26-28]$ is in agreement with observations that pituitary adenomas generally harbour a higher content of IGF-I immunoreactivity than normal pituitary [21] and secrete IGF-I [29].

Thus, a local role of IGF-I in addition to the wellestablished endocrine feed-back mechanism on the GH cells is likely. Therefore, this review addresses the following questions:

1. Is there a phylogenetic consistency of the localisation of IGF-I and the IGF-1R at the pituitary level?

2. Is there a specific role of IGF-I in ontogeny and reproduction?

3. What might be the role of IGF-I in the diverse endocrine cells?

1 Is there a phylogenetic consistency of the localisation of IGF-I at the pituitary level?

In adult mammals, the hormone-producing cell types of the adenohypophysis are arranged in a mosaic pattern [30, 31 ] in contrast to the embryonic state where each specific hormone-producing cell type is located within a particular compartment. This compartmentalisation is preserved in bony fish pituitary throughout a lifetime [32-34] which facilitates identification of the different cell types and, thus, makes bony fish excellent models for morpho-functional investigations. Bony fish pituitary is characterised by a close interdigitating neighbourhood of neurohypophysis (pars nervosa, PN) and adenohypophysis. PRL and ACTH cells are present in the rostral pars distalis (RPD). The proximal pars distalis (PPD) harbours GH cells arranged in a chainlike pattern along the branches of the PN. A small region of the PPD contains the TSH cells, while B-LH cells approximately cover the remaining parts. Centrally, in vicinity to the GH cells the B-FSH cells are located. The pars intermedia (PI) is characterised by peripheral branches of the PN surrounded by somatolactin (SL) and $\alpha-\mathrm{MSH}$ cells. Recently, the distinct localisation of the different cell types was clarified and showed similar distribution patterns among bony fish species [32-34].

In bony fish pituitary, IGF-I mRNA has been detected by PCR in Cottus kazika [35], yellow perch Perca flavescens [36], fathead minnow [37], and tilapia Oreochromis niloticus $[25,38]$ and Oreochromis mossambicus [39]. Additionally IGF-II mRNA has been detected in tilapia [38-40]. IGF-I mRNA and/or immunoreactivity were confined in tilapia to distinct endocrine cell types [25, 41-43] and some pituicytes within the neurohypophysis [25] while pituitary IGF-II has not been localised to distinct cell types to date.

Teleost fish lack a hypothalamo-hypophyseal portal system for the transport of neurohormonal regulators as it exists in mammals. Instead, a direct axonal transport connects the hypothalamic neurons and pituitary endocrine cells via the hypophyseal stalk and the neurohypophysis [33]. This direct regulatory mode is established for the gonadotrophinreleasing hormones (GnRHs) [44, 45], and has been suggested also for the gonadotrophs (GTHs) [34, 45]. In tilapia neurohypophysis, IGF-I peptide occurred in neurosecretory axons but no IGF-I mRNA was detected which indicates that IGF-I is not produced in the neurohypophysis. Instead IGF-I mRNA was found in the hypothalamus so that also IGF-I is assumed to be transported via the axonal stalk from hypothalamic IGF-I-producing neurones as suggested for early development $[42,46]$ and adulthood [25].

In tilapia adenohypophysis (Fig. 1), both IGF-I mRNA and peptide were present in the majority of ACTH cells [25, 41]. In $\alpha$-MSH cells, only IGF-I mRNA but no IGF-I peptide was detected suggesting an immediate release of IGF-I after synthesis (Fig. 1). Whether this is the case also in other species might shed new light on the recently highlighted broad diversity of the POMC family [47]. Also in rat and human, IGF-I mRNA was localized in numerous endocrine cells and IGF-I immunoreactivity was located constantly in almost all ACTH-immunoreactive cells. Using electron microscopy, IGF-I immunoreactivity was confined to secretory granules in co-existence with ACTH immunoreactivity which indicates a concomitant release of both hormones. Thus, also in human and rat, as in tilapia, IGF-I seems to be a constituent in ACTH cells which is also supported by findings in the mouse pituitary corticotroph tumour cell line AtT-20 which has been shown to synthesise and secrete IGFI [48]. Altogether, this points to a well-conserved expression pattern of IGF-I in the ACTH cells.

In rat, human and tilapia $\beta$-TSH cells no IGF-I immunoreactivity was detected [10, 22, 25]. However, first evidence for interactions of the TSH-thyroid gland and the GH/IGF-I axis in fish exist since T3 directly stimulated the hepatic production of IGF-I in the tilapia in vitro and in vivo [49]. Whether there exist interactions also at the level of the pituitary remains to be clarified.

Whereas no IGF-I immunoreactivity was found in the prolactin cells of fish and mammalian species investigated, so far, among the amphibia, in clawed frog (Xenopus laevis) IGF-I immunoreactivity was found exclusively confined to prolactin cells.

In contrast to the exclusive location of IGF-I in some endocrine cell types, IGF-I-binding sites were found ubiquitously spread throughout the pituitary in clawed frog [6]. Furthermore, the IGF-1R has been identified in rat [7-10], ovine [11] and mouse [12] pituitary, particularly on the majority of $\mathrm{GH}$ cells $[10,13,14]$, numerous ACTH cells and, at lower densities, also the other hormone-producing cell types including $\mathrm{LH}$ and FSH cells as well as occasionally prolactin and very rarely $\beta$-TSH cells, indicating a physiological impact of IGF-I for all endocrine cells [10].

2. Is there a specific role of IGF-I in ontogeny and reproduction?

In a study on tilapia pituitary development [42], endocrine cells in the adenohypophysis first exhibited IGF-I mRNA at 28 days post fertilization (DPF). The early presence of different subpopulations of the endocrine cells in tilapia is in general agreement with results obtained in other 
АCTH: anti-apoptotic protection stimulation of proliferation in stress

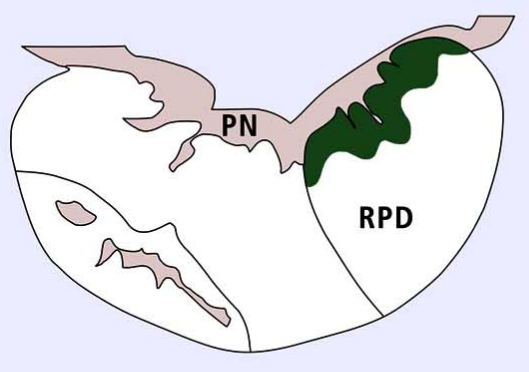

A-MSH: immediate release after synthesis Paracrine stimulation/sustainment of pars nervosa, somatolactin cells

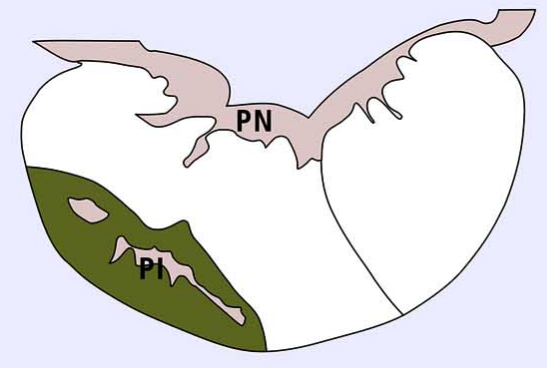

GTH: stimulation of proliferation/release

in puberty, reproduction, social competition

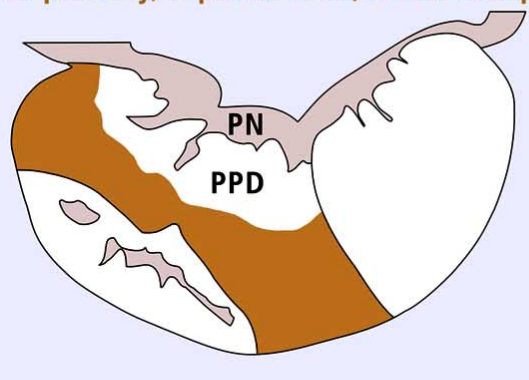

GH: autocrine stimulation of proliferation and release dependent on physiological state

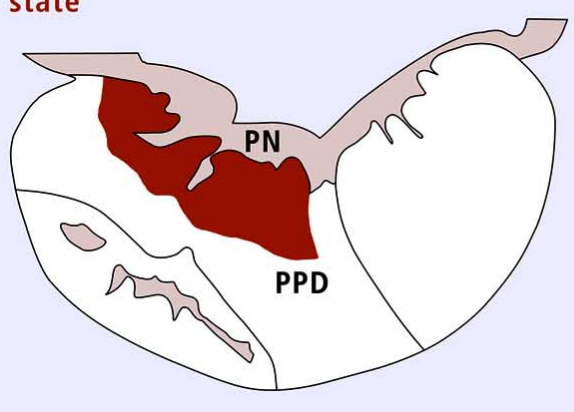

Fig. (1). Schematic drawing of the localisation of IGF-I mRNA/immunoreactivity in tilapia adenohypophysis and assumed autocrine/paracrine functions within the diverse endocrine cell types. Schemes depicted after [25, 34, 42]. RPD: rostral pars distalis. PPD: proximal pars distalis. PI: pars intermedia. PN: pars nervosa.

fish species, such as rainbow trout [50] and American shad [51]. IGF-I mRNA appeared in the $\alpha-\mathrm{MSH}$ and $\mathrm{GH}$ regions from $30 \mathrm{DPF}$ on. Later on, IGF-I mRNA was found in the majority of ACTH cells and $\alpha-\mathrm{MSH}$ cells in all individuals investigated where it persisted throughout life.

Around 30 DPF, IGF-I mRNA also appeared in some cells of GTH regions of female and at 50 DPF of male pituitary [42] which supports the idea that the appearance of IGF-I in the hypothalamic-pituitary-gonad axis is linked to the onset of meiosis in germ cells [52]. During puberty, the expression of IGF-I mRNA in GTH cells was pronounced in the pituitary of both sexes [42]. However, in contrast to findings of Melamed et al. [41], neither IGF-I mRNA nor peptide were detected in GTH cells of young adult tilapia which was attributed to the reproductive stage of the individuals [25]. Indeed, elevated IGF-I gene expression was recently found in GTH regions (Fig. 1) during reproductive phases of both sexes [42].

In the adenopituitary of dominant male tilapia, more $\beta$ LH and less IGF-I mRNA was detected than in normal males while in subordinate males the opposite was present suggesting a role of IGF-I also in sexual competition and social status [43]. The latter is consistent with observations in blue gourami, where $\beta$-LH mRNA was higher in sexually active males when compared to inactive individuals. In contrast, $\beta$-FSH mRNA levels were significantly higher in mature than in juvenile males independent of the sexual activity which generally supports the involvement of $\beta$-FSH in spermatogenesis and of $\beta$-LH in spermiogenesis [53]. Thus, there is increasing evidence for the interference of behavior and social dominance with the hormonal system, not only at the level of steroid receptor expression in brain and pituitary [e.g., 54] but also in the hormone content of the gonadotrophs [43] which might explain the broad variance in IGF-I expression in $\beta$-LH cells as previously observed in adult tilapia [41]. In agreement with the IGF-1R located to rat LH and FSH cells [10], IGF-I has been postulated as important factor for GTH cell action also in mammals since exposure of rat pituitary cells to IGF-I markedly stimulated basal LH and FSH release [55], and augmented basal and Gn-RH-stimulated release of LH in vitro [56-59] whereby in pig the IGF-I-induced increase in basal LH release changed during the oestrous cycle [60].

There is some, but controversial, evidence for a similarly important role in bony fish as most recently emphasized [61, $62]$. In primary cultured pituitary cells of eel, salmon and rainbow trout, IGF-I increased $\beta$-LH cell content and release [63], raised the Gn-RH-stimulated $\beta$-FSH release $[64,65]$ and the intracellular $\beta$-FSH content while the effect on $\beta$-LH cells was less pronounced [64]. Similarly, in primary culture of zebrafish pituitary, IGF-I dose-dependently stimulated gene expression of $\beta$-FSH but not $\beta$-LH [66] while in masu salmon IGF-I directly stimulated both $\beta$-FSH and $\beta$-LH expression and release and modulated GnRH-induced GTH gene expression particularly during early gametogenesis, sexual maturation and reproductive stages [67, 68] which demonstrates that the role of IGF-I in the GTH cells differs among species. Potentiating effects of IGF-I on FSH responses to $\mathrm{GnRH}$ were highest in early gametogenesis [69]. Thus, $\beta$-FSH seems to be generally more susceptible to 
influences by IGF-I, but this demands further studies, especially during different reproductive phases.

3. What is the role of IGF-I in the diverse endocrine cells?

The results indicate that synthesis of IGF-I in the pituitary most likely occurs in endocrine cells with similar distribution patterns in mammals and bony fish suggesting a highly conserved local role of IGF-I in the pituitary. Since a major physiological role of IGF-I is to prevent the onset of apoptosis and promote cell proliferation [70], IGF-I released from the different endocrine cells may have widespread local functions exerted in an either autocrine or paracrine manner (Fig. 1). This hypothesis gets support by the presence of the IGF-1R at cells of all endocrine subpopulations as shown in rat [10] and by the finding that IGF-I stimulated proliferation of cultured mouse endocrine pituitary cells [12] and prevented apoptosis in rat pituitary $[20,71]$.

Since in the adenohypophysis of tilapia, rat and human, IGF-I-immunoreactivity was found in the vast majority of the ACTH cells $[25,41]$, IGF-I seems to be constitutively synthesized in ACTH cells $[10,22,25]$ and to be concomitantly released with ACTH $[10,22]$. However, no effect of IGF-I on ACTH secretion was observed after in vivo application in human although it decreased $\mathrm{GH}$ secretion but did not modify the corticotroph responsiveness to $\mathrm{CRH}$ [72]. Correspondingly, in rat pituitary cultures IGF-I directly inhibited basal and theophylline-stimulated $\mathrm{GH}$ release but did not alter ACTH release [73], and IGF-I exerted no significant effect on basal or $\mathrm{CRH}$-stimulated ACTH release from ovine pituitary [74].

However, the constant presence of IGF-I in ACTH cells suggests other physiological options. As discussed above, IGF-I in mammalian pituitary may serve as a maintenance and proliferation factor when released from endocrine cells. On this basis one can speculate on a particular need of the ACTH cells for IGF-I. Involvement of ACTH cells in stressful situations may lead to challenge with proapoptotic cytokines and thus, require IGF-I to protect against apoptosis. Most recently, neuroendocrine-immune interactions were thoroughly reviewed and the need for more investigations of these interactions especially in central organs was emphasized [75].

As further demonstrated in tilapia, rat and human, IGF-I also occurred in a varying number of GH cells in pituitary. In tilapia, IGF-I mRNA was present in the majority of GH cells during early development [42], the latter suggesting an auto/paracrine function of IGF-I in the proliferation of GH cells (Fig. 1). In later life, however, the number of GH cells containing IGF-I markedly varied among the individuals of different species investigated [10, 22, 25] which explains why IGF-I immunorectivity could not be detected in tilapia GH cells in an earlier study [41]. Thus, there is evidence for a local negative feedback mechanism on the pituitary $\mathrm{GH}$ cells (Fig. 2) in addition to the well-established endocrine route: in vivo experiments in rat showed an inverse relationship between circulating IGF-I and pituitary GH levels [19, 76, 77], and IGF-I inhibited basal and GH-RHstimulated $\mathrm{GH}$ expression and secretion in rat dispersed anterior pituitary cells [78], rat and mouse pituitary cell cultures [27, 55, 79-81], human somatotrophinomas [82], $\mathrm{MtT} / \mathrm{S}$ somatotrophic cells [4], the rat pituitary cell line GH3
[83], and in a bony fish in vitro model of striped bass (Morone saxatilis), white perch (Morone americana) and tilapia (Oreochromis mossambicus) [84], Arctic charr [85], rainbow trout [86] and eel [87]. Very recently, in a pituitary in vitro culture from hybrid striped bass (Morone saxatilis $x$ $M$. chrysops) reared under different environmental conditions (seasonally-based feeding and temperature manipulations) IGF-I inhibited GH release regardless of the metabolic state [88] while in GH-overexpressing transgenic Coho salmon elevated IGF-I serum levels did not significantly suppress pituitary GH expression, a finding which coincided with elevated pituitary IGF-I mRNA levels [89]. Neither did the dropped IGF-I serum levels in GHoverexpressing transgenic tilapia [90] significantly alter pituitary GH expression (as in the Coho salmon mentioned above only mild suppression was measured) [91] while IGFI (and also IGF-II) gene expressions were elevated at the pituitary level [40].

Whereas a positive correlation of body size and plasma IGF-I concentration had been postulated in wild type and GH-overexpressing Coho salmon and tilapia [89, 92, 93] the findings in the growth-enhanced GH-transgenic tilapia [40, $90,91]$ provide more support for the idea that growth may be less due to endocrine mechanisms but to local IGF-I production as has been demonstrated in mice using the Cre/loxP recombination system to delete the IGF-I gene exclusively in the liver [94, 95].

Several studies have shown that estrogen regulates $\mathrm{GH}$ synthesis and secretion in tilapia [96, 97], rat and human [98], the amount of circulating IGF-I in GH-deficient adults [99] and fish [96], and IGF-I mRNA and IGF-I binding in rat pituitary [23]. However, no obvious difference was observed between male and female rats and this was also valid for the portion of GH cells containing IGF-I immunoreactivity [10]. More studies are needed to expand knowledge of the local effects of environmental estrogens on fish pituitary as a central regulatory organ of virtually all physiological processes also in bony fish.

\section{SUMMARY AND CONCLUSIONS}

Altogether, the results in bony fish and mammals indicate a conservative evolution of the pituitary IGF-I system and, thus, particular phylogenetically well preserved physiological functions of local IGF-I. It is assumed that the protective and proliferative effects of IGF-I in pituitary may be exerted not only by circulating but also by local IGF-I released from endocrine cells of the adenohypophysis, and that there exist specific roles for local IGF-I in the pituitary, such as stimulating endocrine cell proliferation, regulating synthesis and release of pituitary hormones, and protecting endocrine cells from apoptosis, especially the ACTH cells. Specific tasks seem to exist for IGF-I in the GTH cells during puberty, reproductive phases and in social competition. In order to enlighten the potential physiological role(s) of IGF-I in distinct endocrine cells, as they have been assumed above, further in vitro studies should be performed with cell lines or culture of primary tissues throughout phylogeny. In addition, the following in vivo experiments in bony fish may be helpful:

1. GH cells: Detailed investigations on IGF-I in GH cells during early and later development, such as 


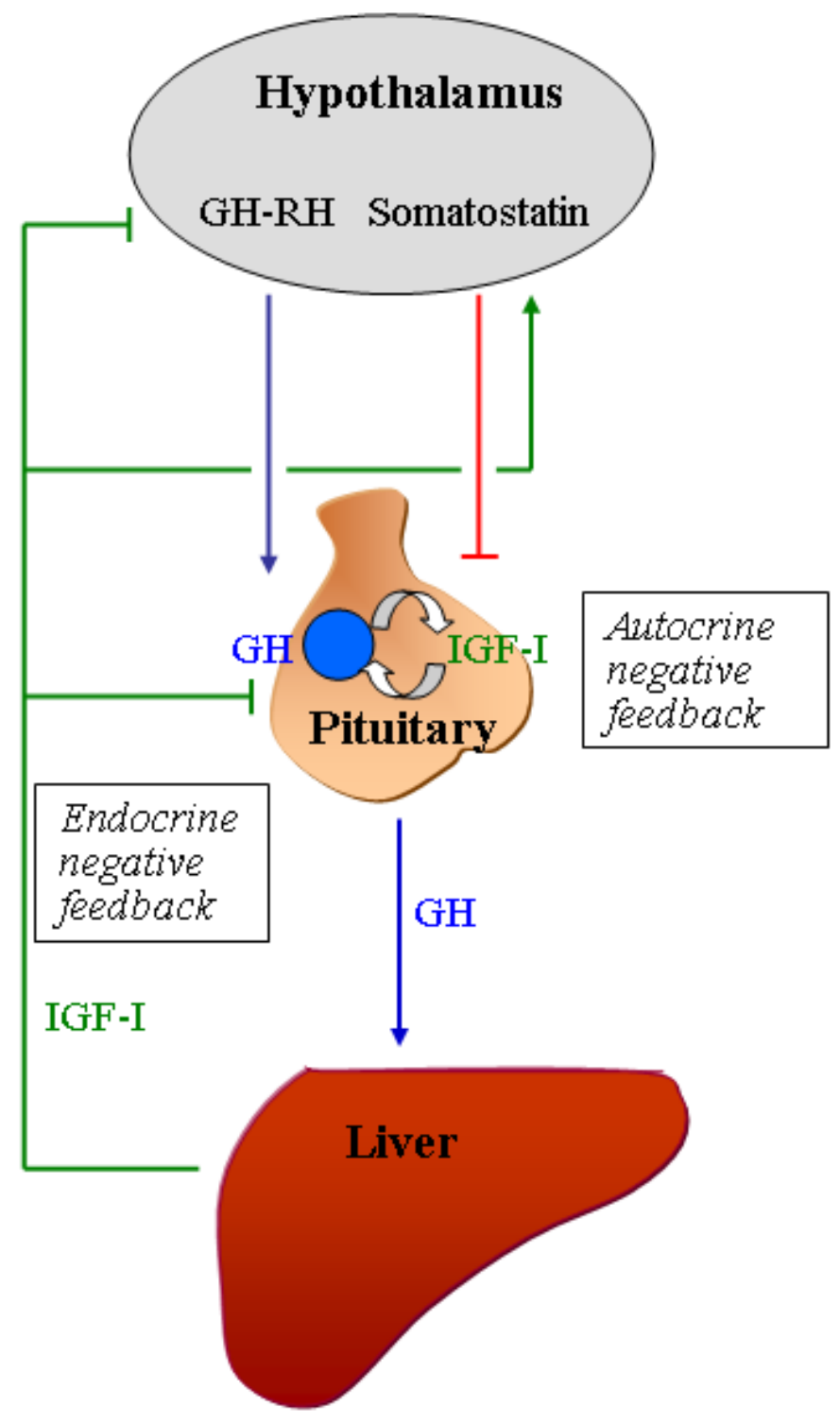

Fig. (2) Hypothetical scheme of the potential autocrine action of local IGF-I in GH cells. GH-RH: GH-releasing hormone.

phases of rapid growth, as well as starvation and refeeding experiments should be performed.

2. ACTH cells: Exposure of fish to stressful situations, such as salinity change or social stress, may help to clarify whether the expression of IGF-I in ACTH cells indeed is constitutive or altered under stress.

3. GTH cells: More detailed studies on the expression of IGF-I in $\beta$-FSH and $\beta$-LH cells during different phases of sexual development and reproductive phases are requested. Furthermore, the potential correlation of the expression levels of IGF-I to the social status of the individual is worth to be investigated.

4. IGF-I peptide in the neuropituitary. Some questions remain. Does the IGF-I peptide within the axonal endings stem from hypothalamic IGF-I producing neurones? What is the physiological role of IGF-I in neuropituitary?

\section{ACKNOWLEDGEMENTS}

The author is grateful to Manfred Reinecke for inspiring discussions and critical reading of the manuscript and to Heinz Sonderegger for graphic design. Special thank is due to Swiss National Science Foundation (Project Nos. 4050$66580 ; 111028,118165)$ and the Hartmann MüllerFoundation for Medical Research (Grants 972, 1115) for generous funding.

\section{REFERENCES}

[1] Jones JI, Clemmons DR. Insulin-like growth factors and their binding proteins: biological actions. Endocr Rev 1995; 16: 3-34.

[2] Reinecke M, Schmid AC, Heyberger-Meyer B, Hunziker EB, Zapf J. Effect of growth hormone and insulin-like growth factor I (IGFI) on the expression of IGF-I messenger ribonucleic acid and peptide in rat tibial growth plate and articular chondrocytes in vivo. Endocrinology 2000; 141: 2847-53.

[3] Fletcher TP, Thomas GB, Dunshea FR, Moore LG, Clarke IJ. IGF feedback effects on growth hormone secretion in ewes: evidence 
for action at the pituitary but not the hypothalamic level. J Endocrinol 1995; 144: 323-31.

[4] Niiori-Onishi A, Iwasaki Y, Mutsuga N, Oiso Y, Inoue K, Saito H. Molecular mechanisms of the negative effect of insulin-like growth factor-I on growth hormone gene expression in $\mathrm{MtT} / \mathrm{S}$ somatotroph cells. Endocrinology 1999; 140: 344-49.

[5] Wallenius K, Sjogren K, Peng XD, et al. Liver-derived IGF-I regulates $\mathrm{GH}$ secretion at the pituitary level in mice. Endocrinology 2001; 142: 4762-70.

[6] David I, Bosshard R, Kloas W, Reinecke M. Insulin-like growth factor I (IGF-I) in the pituitary of Xenopus laevis: Immunocytochemical and autoradiographic indication for a paracrine action and co-release with prolactin. J Neuroendocrinol 2000; 12: 415-20.

[7] Rosenfeld RG, Ceda G, Wilson DM, Dollar LA, Hoffman AR. Characterization of high affinity receptors for insulin-like growth factors I and II on rat anterior pituitary cells. Endocrinology 1984; 114: 1571-75.

[8] Werther GA, Hogg A, Oldfield BJ, et al. Localization and characterization of insulin receptors in rat brain and pituitary gland using in vitro autoradiography and computerized densitometry. Endocrinology 1987; 121: 1562-70.

[9] Olchovsky D, Song J, Gelato MC, et al. Pituitary and hypothalamic insulin-like growth factor-I (IGF-I) and IGF-I receptor expression in food-deprived rats. Mol Cell Endocrinol 1993; 93: 193-98.

[10] Eppler E, Jevdjovic T, Maake C, Reinecke M. Morphology and molecular biology of insulin-like growth factor I (IGF-I) and its receptor IGF-1R in the rat anterior pituitary. Eur J Neurosci 2007a; 25: 191-200.

[11] Adam CL, Gadd TS, Findlay PA, Wathes DC. IGF-I stimulation of luteinizing hormone secretion, IGF-binding proteins (IGFBPs) and expression of mRNAs for IGFs, IGF receptors and IGFBPs in the ovine pituitary gland. J Endocrinol 2000; 166: 247-54.

[12] Oomizu S, Takeuchi S, Takahashi S. Stimulatory effect of insulinlike growth factor I on proliferation of mouse pituitary cells in serum-free culture. J Endocrinol 1998; 157: 53-62.

[13] Yamamoto H, Prager D, Yamasaki H, Melmed S. Rat pituitary GC cell insulin-like growth factor-I receptor regulation. Endocrinology 1993; 133: 1420-25.

[14] Honda J, Takeuchi S, Fukamachi H, Takahashi S. Insulin-like growth factor-I and its receptor in mouse pituitary glands. Zool Sci 1998; 4: 573-79.

[15] Reinecke M, Collet C. The phylogeny of the insulin-like growth factors. Int Rev Cytol 1998; 183: 1-94.

[16] Reinecke M, Björnsson BT, Dickhoff WW, et al. Growth hormone and insulin-like growth factors in fish: where we are and where to go. Gen Comp Endocrinol 2005; 142: 20-24.

[17] Reinecke M. Insulin and the insulin-like growth factors. In: Reinecke M, Zaccone G, Kapoor BG, eds. Fish Endocrinology. Enfield (NH), Jersey, Plymouth, USA: Science Publishers, 2006, Vol. 1: 313 .

[18] Bach MA, Bondy CA. Anatomy of the pituitary insulin-like growth factor system. Endocrinology 1992; 131: 2588-2594.

[19] Olchovsky D, Bruno JF, Gelato MC, Song J, Berelowitz M. Pituitary insulin-like growth factor-I content and gene expression in the streptozotocin-diabetic rat: evidence for tissue-specific regulation. Endocrinology 1991; 128: 923-28.

[20] González-Parra S, Argente J, Chowen JA, et al. Gene expression of the insulin-like growth factor system during postnatal development of the rat pituitary gland. J Neuroendocrinol 2001; 13: 86-93.

[21] Alberti VN, Takita LC, De Mesquita IS, Percario S, Maciel RMB. Immunohistochemical demon-stration of insulin-like growth factor I (IGF-I) in normal and pathological human pituitary glands. Pathol Res Pract 1991; 187: S41-S42.

[22] Jevdjovic T, Bernays R, Eppler E. Insulin-like growth factor I (IGF-I) mRNA and peptide in the human anterior pituitary. J Neuroendocrinol 2007; 19: 335-41.

[23] Michels KM, Lee WH, Seltzer A, Saavedra JM, Bondy CA. Upregulation of pituitary [125I]insulin-like growth factor-I (IGF-I) binding and IGF binding protein-2 and IGF-I gene expression by estrogen. Endocrinology 1993; 132: 23-29.

[24] Ren P, Schelthauer BW, Halper J. Immunohistological localization of TGFalpha, RGF, IGF-I, and TGFbeta in the normal human pituitary gland. Endocr Pathol 1994; 5: 40-48.

[25] Eppler E, Shved N, Moret O, Reinecke M. IGF-I is distinctly located in the bony fish pituitary as revealed for Oreochromis niloticus, the Nile tilapia, using real-time RT-PCR, in situ hybridisation and immunohistochemistry. Gen Comp Endocrinol 2007b; 150: 87-95.

[26] Melmed S, Yamashita S, Yamasaki H, et al. IGF-I receptor signalling: lessons from the somatotroph. Rec Progr Horm Res 1996; 51: 189-215.

[27] Honda J, Manabe Y, Matsumura R, Takeuchi S, Takahashi S. IGFI regulates pro-opiomelanocortin and $\mathrm{GH}$ gene expression in the mouse pituitary gland. J Endocrinol 2003; 178: 71-82.

[28] Wong AOL, Zhou H, Jiang Y, Ko, WKW. Feedback regulation of growth hormone synthesis and secretion in fish and the emerging concept of intrapituitary feedback loop. Comp Biochem Physiol A 2006; 144: 284-305.

[29] Renner U, Mojto J, Arzt E, Lange M, Stalla J, Muller OA, Stalla GK. Secretion of polypeptide growth factors by human nonfunctioning pituitary adenoma cells in culture. Neuroendocrinology 1993; 57: 825-34.

[30] Wingstrand KG. Comparative anatomy and evolution of the hypophysis. In: Harris GW, Donovan BT, Eds. The pituitary gland, London, UK: Butterworths, 1966, Vol. 1: 58-126.

[31] Holmes RL, Ball JN. The pituitary gland - a comparative account London, New York, USA: Cambridge University Press; 1974.

[32] Weltzien FA, Andersson E, Andersen Ø, Shalchian-Tabrizi K, Norberg B. The brain-pituitary-gonad axis in male teleosts, with special emphasis on flatfish (Pleuronectiformes). Comp Biochem Physiol A 2004; 137: 447-77.

[33] Agulleiro B, García-Hernández MP, García Ayala A. Teleost adenohypophysis: morphofunctional and developmental aspects. In: Reinecke M, Zaccone G, Kapoor BG, eds. Fish Endocrinology. Enfield (NH), Jersey, Plymouth, USA: Science Publishers, 2006, Vol. 1: pp. 289-323.

[34] Kasper RS, Shved N, Takahashi A, Reinecke M, Eppler E. A systematic immunohistochemical survey on the distribution patterns of growth hormone, prolactin, somatolactin, ß-TSH, ßFSH, $\beta-\mathrm{LH}, \mathrm{ACTH}$, and $\alpha-\mathrm{MSH}$ in the adenohypophysis of Oreochromis niloticus, the Nile tilapia. Cell Tissue Res 2006; 325 : 303-13.

[35] Inoue K, Iwatani H, Takei Y. Growth hormone and insulin-like growth factor I of a Euryhaline fish Cottus kazika: cDNA cloning and expression after seawater acclimation. Gen Comp Endocrinol 2003; 131: 77-84.

[36] Lynn SG, Shepherd BS. Molecular characterization and sexspecific tissue expression of prolactin, somatolactin and insulin-like growth factor-I in yellow perch (Perca flavescens).Comp Biochem Physiol B Biochem Mol Biol 2007; 147: 412-27.

[37] Filby AL, Tyler CR. Cloning and characterization of cDNAs for hormones and/or receptors of growth hormone, insulin-like growth factor-I, thyroid hormone, and corticosteroid and the gender-, tissue-, and developmental-specific expression of their mRNA transcripts in fathead minnow (Pimephales promelas). Gen Comp Endocrinol 2007; 150: 15-63.

[38] Wang DS, Jiao B, Hu C, Huang X, Liu Z, Cheng CH. Discovery of a gonad-specific IGF subtype in teleost. Biochem Biophys Res Comm 2008; 367:336-41.

[39] Davis LK, Pierce AL, Hiramatsu N, Sullivan CV, Hirano T, Grau EG. Gender-specific expression of multiple estrogen receptors, growth hormone receptors, insulin-like growth factors and vitellogenins, and effects of 17 beta-estradiol in the male tilapia (Oreochromis mossambicus). Gen Comp Endocrinol 2008; 156:544-51.

[40] Eppler E, Berishvili G, Mazel P, et al. Distinct organ-specific upand downregulation of IGF-I and IGF-II mRNA in various organs of a GH-overexpressing transgenic Nile tilapia. Transgenic Res 2010; 19:231-40.

[41] Melamed P, Gur G, Rosenfeld H, Elizur A, Yaron Z. Possible interactions between gonadotrophs and somatotrophs in the pituitary of the tilapia: apparent roles for insulin-like growth factor I and estradiol. Endocrinology 1999; 140: 1183-91.

[42] Moret O, Berishvili G, Shved N, et al. Insulin-like growth factor I (IGF-I) mRNA and peptide in the hypothalamic-pituitary-gonadal axis during development of the tilapia, Oreochromis niloticus. CYBIUM, Int J Ichthyol 2008; 32(2) Suppl.: 31-33.

[43] Shved N, Baroiller J-F, Eppler E. Further insights into the insulinlike growth factor-I system of bony fish pituitary with special emphasis on reproductive phases and social status. Ann NY Acad Sci 2009; 1163: 517-20. 
[44] Somoza GM, Miranda LA, Strobl-Mazzulla P, Guilgur LG. Gonadotropin-releasing hormone $(\mathrm{GnRH})$ : from fish to mammalian brains. Cell Mol Neurobiol 2002; 22:589-609.

[45] Parhar IS, Soga T, Ogawa S, Sakuma Y. FSH and LH- 3 subunits in the preoptic nucleus: ontogenic expression in teleost. Gen Comp Endocrinol 2003; 132: 369-78.

[46] Berishvili G, Shved N, Eppler E, Clota F, Baroiller J-F, Reinecke M. Organ-specific expression of IGF-I during early development of bony fish as revealed in the tilapia, Oreochromis niloticus, by in situ hybridization and immunohistochemistry: indication for the particular importance of local IGF-I. Cell Tissue Res 2006a; 325: 287-301.

[47] Takahashi A, Kobayashi Y, Amano M, Yamanome T. Structural and functional diversity of proopiomelanocortin in fish with special reference to barfin flounder. Peptides 2009; 30: 1374-82.

[48] Schmidt WK, Moore HP. Synthesis and targeting of insulin-like growth factor-I to the hormone storage granules in an endocrine cell line. J Biol Chem 1994; 269: 27115-24.

[49] Schmid AC, Lutz I, Kloas W, Reinecke M. Thyroid hormone stimulates hepatic IGF-I mRNA expression in a bony fish, the tilapia Oreochromis mossambicus, in vitro and in vivo. Gen Comp Endocrinol 2003; 130:129-34.

[50] Saga T, Oota Y, Nozaki M, Swanson P. Salmonid pituitary gonadotrophs. III. Chronological appearance of GTH I and other adenohypophysial hormones in the pituitary of the developing rainbow trout (Oncorhynchus mykiss irideus). Gen Comp Endocrinol 1993; 92: 233-41.

[51] Laiz-Carrión R, del Mar Segura-Noguera M, Martín del Río MP, Mancera JM. Ontogeny of adenohypophyseal cells in the pituitary of the American shad (Alosa sapidissima). Gen Comp Endocrinol 2003; 132: 454-64.

[52] Berishvili G, D’Cotta H, Baroiller J-F, Segner H, Reinecke M. Differential expression of IGF-I mRNA and peptide in the male and female gonad during early development of a bony fish, the tilapia Oreochromis niloticus. Gen Comp Endocrinol 2006b; 146: 204-10.

[53] Degani G, Goldberg D, Tzchori I, Hurvitz A, Yom Din S, Jackson K. Cloning of European eel (Anguilla anguilla) FSH- $\beta$ subunit, and expression of FSH- $\beta$ and LH- $\beta$ in males and females after sex determination. Comp Biochem Physiol B 2003; 136: 283-93.

[54] Burmeister SS, Kailasanath V, Fernald RD. Social dominance regulates androgen and estrogen receptor gene expression. Horm Behav 2007; 51: 164-70.

[55] Pazos F, Sanchez-Franco F, Balsa J, Escalada J, Cacicedo L. Differential regulation of gonadotropins and glycoprotein hormone alpha-subunit by IGF-I in anterior pituitary cells from male rats. J Endocrinol Invest 2004; 27: 670-75.

[56] Kanematsu T, Irahara M, Miyake T, Shitsukawa K, Aono T. Effect of insulin-like growth factor I on gonadotropin release from the hypothalamus-pituitary axis in vitro. Acta Endocrinol (Copenh) 1991; 125: 227-33.

[57] Soldani R, Cagnacci A, Yen SS. Insulin, insulin-like growth factor I (IGF-I) and IGF-II enhance basal and gonadotrophin-releasing hormone-stimulated luteinizing hormone release from rat anterior pituitary cells in vitro. Eur J Endocrinol 1994; 131: 641-45.

[58] Soldani R, Cagnacci A, Paoletti AM, Yen SS, Melis GB. Modulation of anterior pituitary luteinizing hormone response to gonadotropin-releasing hormone by insulin-like growth factor I in vitro. Fertil Steril 1995; 64: 634-37.

[59] Xia YX, Weiss JM, Polack S, Diedrich K, Ortmann O. Interactions of insulin-like growth factor-I, insulin and estradiol with GnRHstimulated luteinizing hormone release from female rat gonadotrophs. Eur J Endocrinol 2001; 144: 73-79.

[60] Whitley NC, Barb CR, Utley RV, Popwell JM, Kraeling RR, Rampacek GB. Influence of stage of the estrous cycle on insulinlike growth factor-I modulation of luteinizing hormone secretion in the gilt. Biol Reprod 1995; 53: 1359-64.

[61] Chang JP, Johnson JD, Sawisky GR, et al. Signal transduction in multifactorial neuroendocrine control of gonadotropin secretion and synthesis in teleosts-studies on the goldfish model Gen Comp Endocrinol 2009; 161: 42-52.

[62] Reinecke M. Insulin-like growth factors and fish reproduction. Biol Reprod 2010; 82: 656-61.

[63] Huang YS, Rousseau K, Le Belle N, et al. Insulin-like growth factor-I stimulates gonadotrophin production from eel pituitary cells: a possible metabolic signal for induction of puberty. J Endocrinol 1998; 159: 43-52.

[64] Baker DM, Davies B, Dickhoff WW, Swanson P. Insulin-like growth factor I increases follicle-stimulating hormone (FSH) content and gonadotropin-releasing hormone-stimulated FSH release from coho salmon pituitary cells in vitro. Biol Reprod 2000; 63: $865-871$.

[65] Rosenfeld H, Levavi-Sivan B, Gur G, et al. Characterization of tilapia FSHbeta gene and analysis of its 5' flanking region. Comp Biochem Physiol B 2001; 129: 389-98.

[66] Lin S-W, Ge W. Differential regulation of gonadotropins (FSH and $\mathrm{LH})$ and growth hormone $(\mathrm{GH})$ by neuroendocrine, endocrine, and paracrine factors in the zebrafish - An in vitro approach. Gen Comp Endocrinol 2009; 160: 183-93.

[67] Ando H, Luo Q, Koide N, Okada N, Urano A. Effects of insulinlike growth factor I on $\mathrm{GnRH}$-induced gonadotropin subunit gene expressions in masu salmon pituitary cells at different stages of sexual maturation. Gen Comp Endocrinol 2006; 149: 21-29.

[68] Furukuma S, Onuma T, Swanson P, et al. Stimulatory effects of insulin-like growth factor 1 on expression of gonadotropin subunit genes and release of follicle-stimulating hormone and luteinizing hormone in masu salmon pituitary cells early in gametogenesis. Zool Sci 2008; 25: 88-98.

[69] Weil C, Carré F, Blaise O, Breton B, Le Bail P-Y. Differential effects of insulin-like growth factor I on in vitro gonadotropin (I and II) and growth hormone secretions in rainbow trout (Oncorhynchus mykiss) at different stages of the reproductive cycle. Endocrinology 1999 ; 140: 2054-62.

[70] Le Roith D, Roberts CT Jr. The insulin-like growth factor system and cancer. Cancer Lett 2003; 195: 127-37.

[71] Fernández M, Sánchez-Franco F, Palacios N, Sánchez I, Fernández C, Cacicedo L. IGF-I inhibits apoptosis through the activation of the phospatidylinositol 3-kinase/Akt pathway in pituitary cells. J Mol Endocrinol 2004; 33: 155-63.

[72] Gianotti L, Ramunni J, Lanfranco F, et al. Recombinant human IGF-I does not modify the ACTH and cortisol responses to hCRH and hexarelin, a peptidyl GH secretagogue, in humans. J Endocrinol Invest 2001; 24: 67-71.

[73] Goodyer CG, De Stephano L, Guyda HJ, Posner BI. Effects of insulin-like growth factors on adult male rat pituitary function in tissue culture. Endocrinology 1984; 115: 1568-76.

[74] Lu F, Yang K, Han VK, Challis JR. Expression, distribution, regulation and function of IGFs in the ovine fetal pituitary. $\mathrm{J}$ Mol Endocrinol 1995; 14: 323-36.

[75] Verburg-Van Kemenade BML, Stolte EH, Metz JR, Chadzinska M. Neuroendocrine-immune interactions in teleost fish. In: Bernier NJ, Van der Kraah G, Farrell AP, Brauner CJ, Eds: Fish Physiol 2009; 28: 313-64.

[76] Abe H, Molitch ME, Van Wyk JJ, Underwood LE. Human growth hormone and somatomedin $\mathrm{C}$ suppress the spontaneous release of growth hormone in unanesthetized rats. Endocrinology 1983; 113: 1319-24.

[77] Tannenbaum GS, Guyda HJ, Posner BI. Insulin-like growth factors: a role in growth hormone negative feedback and body weight regulation via brain. Science 1983; 220: 77-79.

[78] Sheppard MS, Bala RM. Insulin-like growth factor inhibition of growth hormone secretion. Can J Physiol Pharmacol 1986; 64: 52530 .

[79] Yamashita S, Melmed S. Effects of insulin on rat anterior pituitary cells. Inhibition of growth hormone secretion and mRNA levels. Diabetes 1986; 35: 440-47.

[80] Simes JM, Wallace JC, Walton PE. The effects of insulin-like growth factor-I (IGF-I), IGF-II and des(1-3)IGF-I, a potent IGF analogue, on growth hormone and IGF-binding protein secretion from cultured rat anterior pituitary cells. J Endocrinol 1991; 130: 93-99.

[81] Lara JI, Lorenzo MJ, Cacicedo L, et al. Induction of vasoactive intestinal peptide gene expression and prolactin secretion by insulin-like growth factor I in rat pituitary cells: evidence for an autoparacrine regulatory system. Endocrinology 1994; 135: 252632.

[82] Atkin SL, Landolt AM, Foy P, Jeffreys RV, Hipkin L, White MC. Effects of insulin-like growth factor-I on growth hormone and prolactin secretion and cell proliferation of human somatotrophinomas and prolactinomas in vitro. Clin Endocrinol 1994; 41: 503-9. 
[83] Castillo AI, Aranda A. Differential regulation of pituitary-specific gene expression by insulin-like growth factor 1 in rat pituitary GH4C1 and GH3 cells. Endocrinology 1997; 138: 5442-51.

[84] Fruchtman S, Jackson L, Borski R. Insulin-like growth factor I disparately regulates prolactin and growth hormone synthesis and secretion: studies using the teleost pituitary model. Endocrinology 2000; 141: 2886-94.

[85] Cameron C, Moccia RD, Leatherland JF. Growth hormone secretion from the Arctic charr (Salvelinus aplinus) pituitary gland in vitro: effects of somatostatin-14, insulin-like growth factor-I, and nutritional status. Gen Comp Endocrinol 2005; 141: 93-100.

[86] Perez-Sanchez J, Weil C, Le Bail PY. Effects of human insulin-like growth factor-I on release of growth hormone by rainbow trout (Oncorhynchus mykiss) pituitary cells. J Exp Zool 1992; 262: 28790.

[87] Rousseau K, Huang YS, Le Belle N, et al. Long-term inhibitory effects of somatostatin and insulin-like growth factor 1 on growth hormone release by serum-free primary culture of pituitary cells from European eel (Anguilla anguilla). Neuroendocrinology 1998; 67: 301-19.

[88] Picha ME, Strom CN, Riley LG, Walker AA, Won ET, Johnstone WM, Borski RJ. Plasma ghrelin and growth hormone regulation in response to metabolic state in hybrid striped bass: effects of feeding, ghrelin and insulin-like growth factor-I on in vivo and in vitro GH secretion. Gen Comp Endocrinol 2009; 161:365-72.

[89] Raven PA, Uh M, Sakhrani D, et al. Endocrine effects of growth hormone overexpression in transgenic coho salmon. Gen Comp Endocrinol 2008; 159:26-37.

[90] Eppler E, Caelers A, Shved N, et al. Insulin-like growth factor I (IGF-I) in a growth-enhanced transgenic (GH-overexpressing) bony fish, the tilapia (Oreochromis niloticus): indication for a higher impact of autocrine/paracrine than of endocrine IGF-I. Transgenic Res 2007c;16:479-89.

[91] Caelers A, Maclean N, Hwang G, Eppler E, Reinecke M. Expression of endogenous and exogenous growth hormone $(\mathrm{GH})$ in a GH-transgenic tilapia (Oreochromis niloticus). Transgenic Res 2005; 14: 95-104.

[92] Pierce AL, Dickey JT, Larsen DA, Fukada H, Swanson P, Dickhoff WW. A quantitative real-time RT-PCR assay for salmon IGF-I mRNA, and its application in the study of GH regulation of IGF-I gene expression in primary culture of salmon hepatocytes. Gen Comp Endocrinol 2004; 135:401-11

[93] Uchida K, Kajimura S, Riley LG, Hirano T, Aida K, Grau EG. Effects of fasting on growth hormone/insulin-like growth factor I axis in the tilapia, Oreochromis mossambicus. Comp Biochem Physiol A Mol Integr Physiol 2003; 134:429-39.

[94] Sjögren K, Liu JL, Blad K, et al. Liver-derived insulin-like growth factor I (IGF-I) is the principal source of IGF-I in blood but is not required for postnatal body growth in mice. Proc Natl Acad Sci USA 1999; 96:7088-7092.

[95] Yakar S, Liu JL, Stannard B, et al. Normal growth and development in the absence of hepatic insulin-like growth factor I. Proc Natl Acad Sci U S A 1999; 96:7324-29.

[96] Shved N, Berishvili G, Baroiller J-F, Segner H, Eppler E, Reinecke M. Ethinylestradiol differentially interferes with the IGF-I system in the tilapia, Oreochromis niloticus. J Endocrinol 2007; 195: 51323.

[97] Shved N, Berishvili G, Baroiller JF, Segner H, Reinecke M. Environmentally relevant concentrations of 17alphaethinylestradiol (EE2) interfere with the growth hormone $(\mathrm{GH})$ /insulin-like growth factor (IGF)-I system in developing bony fish. Toxicol Sci 2008; 106: 93-102.

[98] Chowen JA, Frago LM, Argente J. The regulation of GH secretion by sex steroids. Review. Eur J Endocrinol 2004; 151 (Suppl 3): U95-100.

[99] Jorgensen JO, Christensen JJ, Krag M, Fisker S, Ovesen P, Christiansen JS. Serum insulin-like growth factor I levels in growth hormone-deficient adults: influence of sex steroids. Horm Res 2004; 62 (Suppl 1): 73-76

\section{(c) Elisabeth Eppler; Licensee Bentham Open.}

This is an open access article licensed under the terms of the Creative Commons Attribution Non-Commercial License (http://creativecommons.org/licenses/by-nc/3.0/) which permits unrestricted, non-commercial use, distribution and reproduction in any medium, provided the work is properly cited. 